\title{
KOMPARASI PENGENDALI PI DAN PID UNTUK TEGANGAN KELUARAN KONVERTER BUCK
}

\author{
Irma Husnaini dan Krismadinata* \\ Jurusan Teknik Elektro, Fakultas Teknik, Universitas Negeri Padang \\ *Corresponding author, e-mail : krisma@ft.unp.ac.id
}

\begin{abstract}
Abstrak-Tulisan ini membahas komparasi tanggapan dinamik dari tegangan keluaran konverter buck dengan menerapkan pengendali Proportional Integral (PI) dan Proportional Integral Derivative (PID). Perancangan dan simulasi tegangan keluaran konverter buck ini dilakukan menggunakan Matlab. Unjuk kerja dari konverter buck dianalisa secara teoritis dan grafis. Hasil simulasi memperlihatkan penerapan pengendali PID pada konverter buck memiliki unjuk kerja lebih baik dibandingkan pengendali PI.
\end{abstract}

Kata Kunci : Konverter buck, PI, PID

\begin{abstract}
This paper discusses comparison of the output voltage dynamic response of buck converter that employing controller Proportional Integral (PI), and Proportional Integral Derivative (PID). Design and simulation of a buck converter output voltage is performed using Matlab. The performance of buck converter has been verified by the theoretically and graphically. Those simulations shown that PID controller has been better performance than the PI controller.
\end{abstract}

Keywords :, Buck converter, PI, PID

Copyright () 2017 JNTE. All rights reserved

\section{PENDAhULUAN}

Konverter buck yang merupakan salah satu jenis konverter DC-DC yang banyak digunakan dalam berbagai aplikasi seperti untuk catu daya komputer, peralatan elektronik untuk kesehatan, peralatan elektronik untuk rumah tangga, transportasi elektrik, pesawat ruang angkasa, peralatan telekomunikasi, konverter daya untuk energi terbarukan dan sebagainya. Dengan banyaknya aplikasi dari konverter DC-DC ini, dibutuhkan banyak penelitian yang mengkaji bidang ini.

Konverter buck merupakan rangkaian elektronika daya yang dapat menurunkan level tegangan DC menjadi level tegangan DC yang lebih rendah sesuai kebutuhan. Dikarenakan konverter buck menggunakan saklar daya, komponen pasif seperti induktor dan kapasitor yang merupakan sistem non-linear, sehingga metoda kendali yang digunakan untuk mengendalikan konverter berdampak langsung pada unjuk kerja konverter $[1,2]$.

Pada umumnya tegangan keluaran konverter buck berubah berdasarkan perubahan tegangan masukan atau akibat variasi beban. Perubahan nilai tegangan keluaran tergantung pada tapis induktor dan nilai kapasitor dalam rangkaian dan frekuensi pensaklaran serta algoritma kontroler. Jika nilai induktor, kapasitor dan frekuensi penskalaran tetap, perbedaan algoritma pengendali menghasilkan perbedaan tanggapan dinamik [3].

Berbagai metoda kendali telah banyak diaplikasikan dalam mengendalikan tegangan keluaran konverter DC-DC seperti penempatan kutub [4], LQR [5], lingkar umpan-balik [6], kendali ruang keadaan [7] dan kontroler Fuzzy [8].

Metoda kendali PI dan PID banyak digunakan untuk kendali konverter DC-DC, dikarenakan secara praktis lebih mudah dalam perancangan dan menerapkannya pada sistem konverter. Akan tetapi, pemilihan parameterparameter pengendali yang tepat untuk kendali PI dan PID sulit didapat karena adanya komponen pasif pada konverter DC-DC serta perubahan tegangan masukan dan tegangan beban terhadap waktu [9], sehingga parameter pengendali PI dan PID perlu dirancang secara efektif untuk memperoleh suatu tanggapan peralihan yang kokoh.

Berbagai metoda klasik telah dikembangkan untuk mendapat parameter pengendali PI dan 
PID yang kokoh [10, 11]. Diantaranya dengan dengan menggunakan metoda Ziegler-Nichols (ZN) dan tanggapan frekuensi [12].

Pada artikel ini, pengendalian tegangan keluaran konverter buck dilakukan dengan menggunakan pengendali PI dan PID. Pemilihan parameter pengendali dilakukan dengan metoda tanggapan frekuensi untuk mendapatkan nilai parameter-parameter pengendali yang paling optimal sehingga sistem stabil dan memiliki galat dalam keadaan mantap adalah nol. Kedua pengendali ini dirancang, disimulasikan dan dianalisa serta dilakukan perbandingan dalan hal unjuk kerja terhadap keluaran konverter buck.

\section{TINJAUAN PUSTAKA}

\subsection{Model Matematik Konverter Buck}

Konverter buck sebagai salah satu regulator mode pensaklaran menghasilkan tegangan keluaran yang lebih kecil dibanding tegangan masukannya. Rangkaian konverter buck secara sederhana terdiri atas satu saklar aktif (MOSFET), satu saklar pasif (dioda), kapasitor, dan induktor sebagai tapis keluarannya serta beban resistor. Rangkaian Konverter buck dapat dilihat pada Gambar 1.

Saklar aktif berfungsi mencincang tegangan masukan dari konverter buck dengan frekuensi tinggi dan mengubah tegangan masukan dengan amplitudo konstan menjadi bentuk gelombang kotak. Kemudian tegangan keluaran DC ratarata $V_{o}$ diperoleh dari gelombang kotak ini dengan melewatkan pada tapis induktor dan kapasitor.

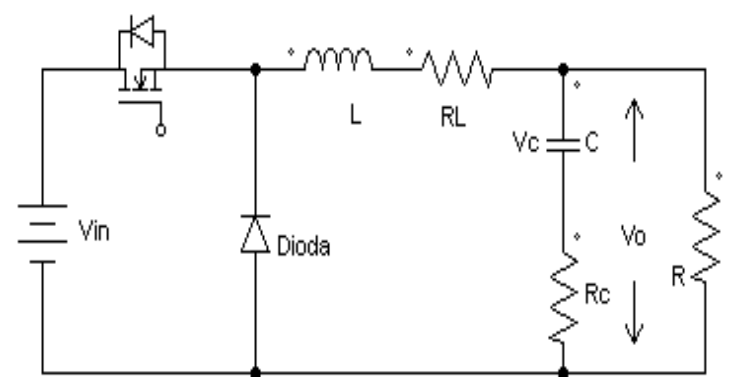

Gambar 1.Rangkaian konverter buck

Prinsip kerja konverter buck pada saat semua komponen diasumsikan ideal dan konverter beroperasi dalam kondisi Continuous Current Mode (CCM) dapat dibagi menjadi 2 mode operasi yaitu: mode 1 ketika saklar aktif tertutup danmode 2 ketika saklar aktif terbuka.

Pada mode 1: Ketika Saklar aktif on (tertutup) dan dioda off, arus mengalir dari sumber menuju ke induktor (pengisian induktor), ditapis dengan kapasitor, lalu ke beban, kembali lagi ke sumber, ini dapat dilihat pada Gambar 2.

Pada saat mode 2, dioda dalam keadaan bias maju ini ditunjukan oleh Gambar 3. Ketika Saklar aktif off (terbuka) dan dioda on, arus yang disimpan induktor dikeluarkan menuju beban lalu ke dioda freewheeling dan kembali lagi ke induktor.

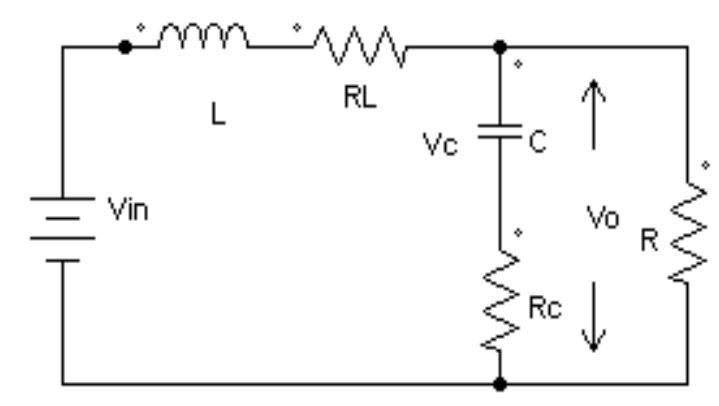

Gambar 2. Mode 1, Saklar tutup.

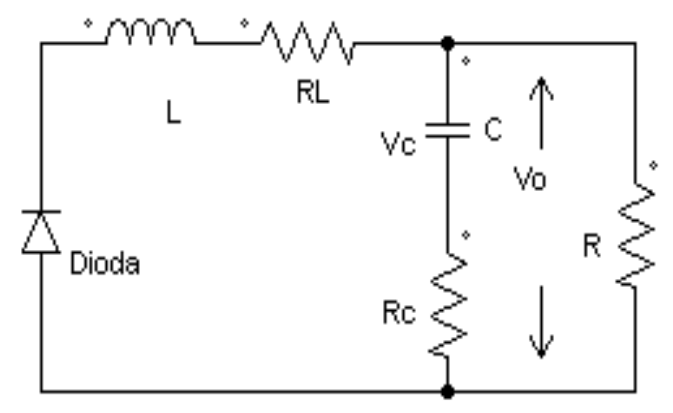

Gambar 3: Mode 2, Saklar buka

Model matematis konverter buck untuk kedua mode dapat didefinisikan sebagai berikut: Ketika Saklar aktif on:

$$
\begin{aligned}
& \frac{d i_{L}}{d t}=\frac{V_{i n}}{L}-i_{L} \frac{1}{L}\left(R_{L}+\frac{R \times R_{C}}{R+R_{C}}\right)-v_{C} \frac{1}{L}\left(1-\frac{R_{C}}{R+R_{C}}\right) \\
& \frac{d v_{C}}{d t}=i_{L} \frac{1}{C}\left(\frac{R}{R+R_{C}}\right)-v_{C} \frac{1}{C}\left(\frac{1}{R+R_{C}}\right)
\end{aligned}
$$

Bentuk persamaan keadaan dari persamaan (1) dan (2) adalah : 


$$
\frac{d}{d t}\left[\begin{array}{c}
i_{L} \\
v_{C}
\end{array}\right]=[A] \times\left[\begin{array}{c}
i_{L} \\
v_{C}
\end{array}\right]+\left[\begin{array}{c}
\frac{V_{i n}}{L} \\
0
\end{array}\right]
$$

Dimana:

$$
A=\left[\begin{array}{cc}
\frac{1}{L}\left(R_{L}+\frac{R \times R_{C}}{R+R_{C}}\right) & \frac{1}{L}\left(1-\frac{R_{C}}{R+R_{C}}\right) \\
\frac{R}{C \times\left(R+R_{C}\right)} & \frac{-1}{C \times\left(R+R_{C}\right)}
\end{array}\right]
$$

Ketika Saklar aktif off:

$$
\begin{aligned}
& \frac{d i_{L}}{d t}=-i_{L} \frac{1}{L}\left(R_{L}+\frac{R \times R_{C}}{R+R_{C}}\right)-v_{C} \frac{1}{L}\left(1-\frac{R_{C}}{R+R_{C}}\right) \\
& \frac{d v_{C}}{d t}=i_{L} \frac{1}{C}\left(\frac{R}{R+R_{C}}\right)-v_{C} \frac{1}{C}\left(\frac{1}{R+R_{C}}\right)
\end{aligned}
$$

Bentuk persamaan keadaan dari persamaan (4) dan (5) adalah :

$$
\frac{d}{d t}\left[\begin{array}{c}
i_{L} \\
v_{C}
\end{array}\right]=\left[\begin{array}{cc}
\frac{1}{L}\left(R_{L}+\frac{R \times R_{C}}{R+R_{C}}\right) & \frac{1}{L}\left(1-\frac{R_{C}}{R+R_{C}}\right) \\
\frac{R}{C \times\left(R+R_{C}\right)} & \frac{-1}{C \times\left(R+R_{C}\right)}
\end{array}\right] \times\left[\begin{array}{c}
i_{L} \\
v_{C}
\end{array}\right]
$$

Dimana $V_{\text {in }}$ adalah tegangan masukan konverter, $R_{L}$ tahanan dalam induktor, $R_{c}$ tahanan dalam kapasitor, $i_{L}$ arus induktor, $v_{C}$ tegangan kapasitor, $L$ simbol untuk induktansi, $C$ simbol kapasitansi, $R$ adalah simbol tahanan beban dan $V_{o}$ adalah tegangan keluaran dari konverter buck.

Nilai rata-rata tegangan keluaran konverter $V_{o}$ sebanding dengan rasio antara waktu penutupan saklar (saklar on) terhadap periode penyaklarannya, yang dikenal dengan duty ratio atau duty cycle $(D)$ statis. Formula ini diilustrasikan dalam persamaan (7) dan (8).

$$
D=\frac{T_{o n}}{T_{o n}+T_{\text {off }}}
$$

$$
\text { Dimana } T=T_{o n}+T_{\text {off }}
$$

$$
V_{o}=D \times V_{\text {in }}
$$

Biasanya nilai duty ratio ini tidak lebih kecil dari 0.2, karena jika dioperasikan pada rasio tegangan yang lebih tinggi, saklar akan bekerja dibawah keandalannya dan menyebabkan efisiensi konverter turun.
Persamaan fungsi alih konverter buck untuk perbandingan tegangan keluaran terhadap duty ratio dinamis ditulis dalam bentuk;

$$
\frac{\hat{v}_{o}(s)}{d(s)}=\frac{R\left(1+s R_{c} C\right)}{L C s^{2}\left(R+R_{C}\right)+s\left(L+R C R_{C}\right)+R} \times V_{i n}
$$

Dari persamaan (9), terlihat bahwa fungsi alih konverter ini merupakan bervariasi terhadap fungsi frekuensi sehingga karakteristik dari konverter buck dapat dianalisis dalam ranah frekuensi.

Penentuan berapa besar nilai komponen konverter buck dapat menggunakan formula sebagai berikut:

Riak arus $=\Delta I_{L}=V_{0}\left(T-T_{\text {on }}\right) / L$

Induktansi minimum $=L_{\min }=\frac{(1-D) R}{2 f}$

Dengan mengasumsikan riak arus $10 \%$ s.d. $20 \%$ maka besar nilai induktansi, $L$ adalah:

$$
L=\frac{V_{\text {in }} D(1-D)}{f \Delta I_{L}}
$$

Dan mengasumsikan riak tegangan 1 s.d 2\% maka besar nilai kapasitansi kapasitor, $C$ adalah

$$
C=\frac{V_{\text {in }} D(1-D)}{8 L f^{2} \Delta V_{C}}
$$

\subsection{Karateristik Tanggapan Peralihan}

Karateristik kinerja suatu sistem kendali biasanya menggunakan masukan sinyal undak satuan (step). Berdasarkan persamaan (9) fungsi alih konverter buck merupakan sistem berorde2. Parameter sistem orde-2 didefinisikan sebagai berikut: $\omega_{n}$ adalah frekuensi alami tak teredam (natural frequency). $\zeta$ adalah konstanta perbandingan peredaman (damping ratio). $\omega_{d}$ adalah frekuensi alami yang teredam (damped natural frequency). Untuk sistem berorde-2 dengan $0<\zeta<1$ dan $\omega_{n}>0$ tanggapan step sistem ditunjukkan pada Gambar 4.[13, 14]. 


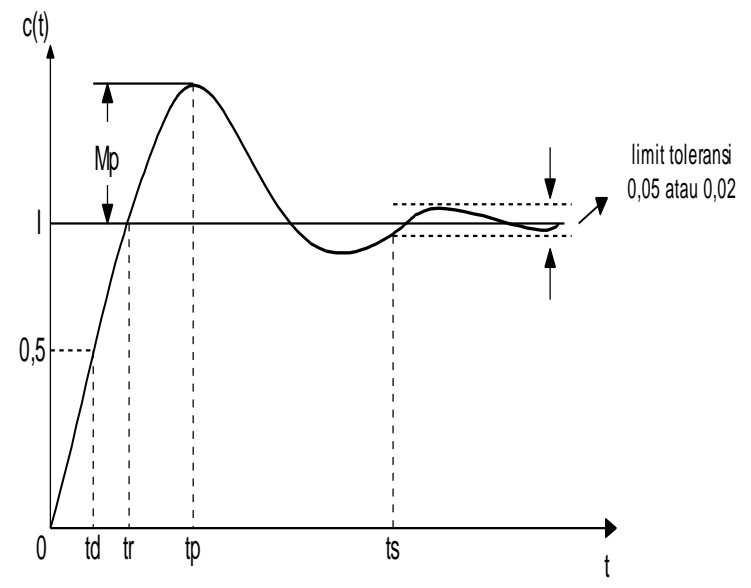

Gambar 4. Tanggapan step sistem orde-2 untuk kasus teredam kurang

Dalam tanggapan peralihan ada beberapa hal yang akan ditentukan besarannya, antara lain adalah sebagai berikut $[13,14]$.

1. Waktu naik $\left(\mathbf{t}_{\mathbf{r}}\right)$ : Waktu yang dibutuhkan agar tanggapan naik dari: $10 \%$ ke $90 \%$. Pendekatan untuk rise time

$$
t_{r}=\frac{1}{\omega_{d}} \tan ^{-1}\left(\frac{\omega_{d}}{-\sigma}\right)=\frac{\pi-\beta}{\omega_{d}}
$$

\section{Persentase simpang pucak, $M_{p}$ :}

Perbandingan antara nilai puncak puncak tertingi dari kurva tanggapan terhadap nilai akhir tanggapan

$$
\% M_{p}=e^{-\left(\pi \pi^{\prime} / \sqrt{1-\varsigma^{2}}\right)} x 100
$$

Puncak overshoot digunakan untuk menyatakan kestabilan relatif. Sistem dengan overshoot sekitar $40 \%$ mengindikasikan ketidakstabilan. Rancangan sistem biasanya dengan overshoot berkisar 5-25\%. Kadang diharapkan sistem tanpa overshoot.

\section{Waktu Menetap ( $\left.t_{s}\right)$}

Waktu yang dibutuhkan agar kurva tanggapan mencapai dan tetap berada didalam batas-batas yang dekat dengan nilai akhir

$$
t_{s}=4 T=\frac{4}{\sigma}=\frac{4}{\xi \omega_{n}} \text { untuk steady state } 2 \%
$$

Faktor redaman $(\zeta)$ dan frekuensi alami tak teredam $\left(\omega_{n}\right)$ menentukan tanggapan transien dan kecepatan tanggpan sistem. Untuk tanggapan yang cepat $\omega_{n}$ harus besar. Jika faktor redaman $\xi<0,4$ menyebabkan overshoot yang berlebihan pada tanggapan transien dan sistem dengan $\xi>0,8$ membuat tanggapan sistem lambat. Sehingga $\xi$ ditetapkan $0,4<\xi<0,8$, maka overshoot maksimum (\%) untuk step respons adalah di antara $25 \%$ dan 2,5\%. Kestabilan sistem dapat diketahui dengan menggunakan bode diagram. Gain margin didefinisikan sebagai perubahan dalam penguatan yang dikehendaki lingkar terbuka yang membuat sistem tidak stabil. Fasa margin didefinisikan sebagai perubahan dalam penggeseran fasa lingkar terbuka yang ditetapkan untuk membuat sistem lingkar tertutup tidak stabil.
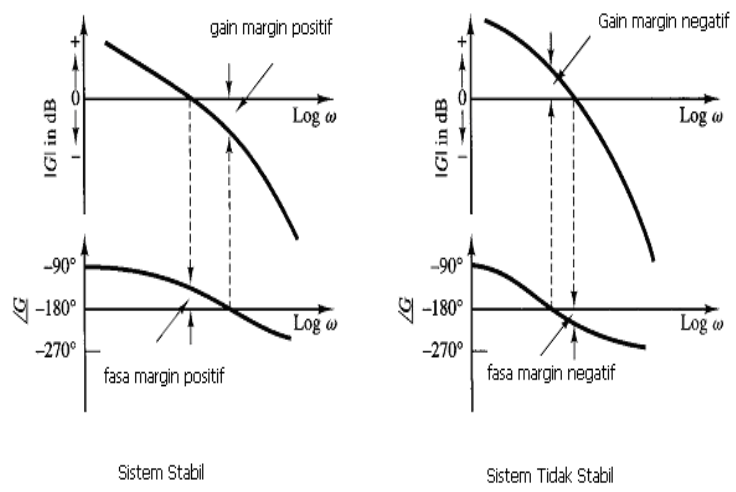

Gambar 5. Diagram bode dengan untuk sistem stabil dan tidak stabil

Berdasarkan gambar dapat dilihat gain margin dan fasa margin positif, berarti sistem stabil dan sebaliknya sistem tidak stabil. Sistem kendali dengan margin kestabilan cukup mempunyai fasa margin $45^{0}$ atau lebih, dengan gain margin $8 \mathrm{~dB}$ atau lebih. Besarnya fasa margin yang diinginkan diperoleh $\phi_{P M}=100 \xi$ . Fasa margin menentukan tanggapan peralihan konverter buck. Peningkatan fasa margin membuat sistem lebih stabil dengan mengurangi osilasi.

\subsection{Pengendali PI}

Untuk menghasilkan tegangan keluaran yang konstan, konverter buck dapat ditambah dengan rangkaian umpan balik. Pada rangkaian 
umpan balik ini, tegangan keluaran dari konverter buck akan dibandingkan dengan tegangan referensi, selisih keduanya akan digunakan untuk menentukan duty ratio yang perlu ditambah atau dikurang sehingga menghasilkan tegangan keluaran yang konstan.

Pada Gambar 6 ditunjukan blok diagram sistem kendali PI. Tegangan keluaran konverter buck $V_{o}(t)$ diukur menggunakan sensor, kemudian dibandingkan dengan tegangan referensi menghasilkan galat $e(t)$, ini menjadi masukan pada blok pengendali PI. Keluaran dari blok pengendali PI $u(t)$ menjadi masukan pada blok pembangkit sinyal PWM (pulse width modulation), Sinyal inilah yang akan masuk ke rangkaian gate drive, $\delta(t)$ yang akan menyalakan MOSFET konverter buck.

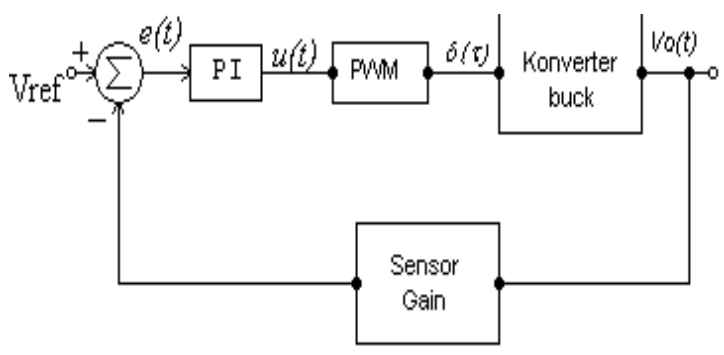

Gambar 6. Blok Diagram Pengendali PI

Jika $e(t)$ adalah masukan ke alat kontrol PI dan $u(t)$ adalah keluaran alat kontrol, maka bentuk persamaan pengendali PI adalah sebagai berikut.

$$
u(t)=K_{p} e(t)+K_{i} \int_{0}^{t} e(t) d t
$$

Sehingga bentuk persamaan dalam domain frekuensi,

$$
\frac{U(s)}{E(s)}=K_{p}\left(1+\frac{1}{T_{i} s}\right)
$$

Sehingga fungsi alihnya dapat ditulis sebagai berikut

$$
G_{c}(s)=K_{p}+\frac{K_{i}}{s}=\frac{K_{p} s+K_{i}}{s}
$$

Adapun prosedur perancangan pengendali PI menggunakan tanggapan frekuensi adalah sebagai berikut [12]:
1. Menghitung frekuensi $\omega_{1}$ dimana sudut $\mathrm{G}\left(\mathrm{j} \omega_{w}\right)$ sama dengan $\left(-180^{\circ}+\phi_{\mathrm{m}}{ }^{\circ}+5^{\circ}\right)$, dengan $\phi_{\mathrm{m}}$ merupakan margin fasa yang dikehendaki.

2. Tentukan nilai $K_{p}=\frac{1}{\mid G\left(j \omega_{1}\right) H\left(j \omega_{1} \mid\right.}$

3 . Hitung magnitude 0 dengan persamaan

$\omega_{0}=0,1 \omega_{1}$

sehingga

$$
K_{I}=\omega_{0} \cdot K_{p}
$$

4. Hitung fungsi alih Pengendali PI.

Dengan adanya elemen integral pada pengendali PI, maka galat offset pada mode pengendali porposional $(\mathrm{P})$ dapat dihilangkan. Disisi lain pengendali ini dapat menekan kecendrungan osilasi.

\subsection{Pengendali PID}

Blok diagram sistem pengendali PID untuk konverter buck tidak jauh beda dengan pengendali PI, hanya menambahkan satu blok pengendali derivative. Sesuai namanya PID (proporsional, integral, dan derivative) merupakan pengendali yang mengabungkan 3 buah jenis pengendali dengan karakteristiknya masing-masing. Blok diagram sistem kendali menggunakan pengendali PID diperlihatkan pada Gambar 7.

Persamaan Pengendali PID dapat ditulis:

$u(t)=K\left(e(t)+\frac{1}{T_{i}} \int_{0}^{t} e(t) d t+T_{d} \frac{d e(t)}{d t}\right)$

Pengendali PID memiliki fungsi alih sebagai berikut:

$G_{c}(s)=K_{p}\left(1+\frac{1}{T_{i} s}+T_{d}(s)\right)$

$G_{c}(s)=K_{p}+\frac{K_{i}}{s}+K_{d} s$

dengan

$K_{p}=$ penguatan proporsional

$T_{i}$ = waktu integral

$T_{d}=$ waktu turunan

$K_{i}=$ penguatan integral

$K_{d}=$ pengauatan turunan (derivatif) 


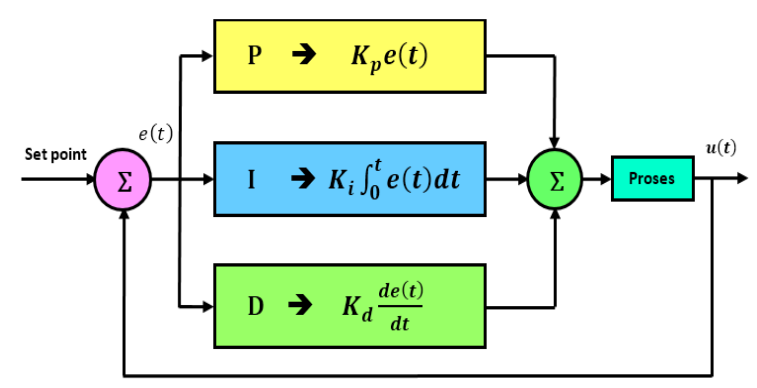

Gambar 7. Blok Diagram Pengendali PID

Proses pemilihan parameter-parameter pengendali $K_{p}, K_{i}$ dan $K_{d}$ agar memenuhi spesifikasi yang diberikan sesuai dengan prosedur perancangan menggunakan tanggapan frekuensi. Adapun prosedur perancangan pengendali PID adalah sebagai berikut [13]:

1. Menghitung frekuensi $\omega_{1}$ dimana sudut $\mathrm{G}\left(\mathrm{j} \omega_{w}\right)$ sama dengan $\left(-180^{\circ}+\phi_{\mathrm{m}}{ }^{\circ}\right.$ $\left.\angle G\left(j \omega_{1}\right) H\left(j \omega_{1}\right)\right)$, dengan $\phi_{\mathrm{m}}$ merupakan margin fasa yang dikehendaki.

2. Tentukan nilai $K_{p}=\frac{\operatorname{Cos} \theta}{\mid G\left(j \omega_{1}\right) H\left(j \omega_{1} \mid\right.}$

3. $K_{D}=\left[\frac{\sin \theta}{\omega_{1}\left|G\left(j \omega_{1}\right)\right| H\left(j \omega_{1}\right)}\right]+\frac{K_{I}}{\omega_{1}^{2}}$

4. Hitung fungsi alih pengendali PID.

\section{METODOLOGI}

Penelitian ini dilaksanakan dengan metoda simulasi menggunakan bantuan perangkat lunak Matlab. Kendali tegangan keluaran konverter buck dilakukan menggunakan pengendali PI dan PID.

Pengujian dilakukan untuk melihat unjuk kerja pengendali yang berhubungan dengan tanggapan peralihan (transient) sistem dalam menggendalikan tegangan keluaran konverter buck. Unjuk kerja konverter buck dalam berbagai pengendali diamati dalam bentuk grafik.

Penelitian diawali dengan melihat tanggapan tegangan keluaran dan Bode plot konverter buck tanpa menggunakan pengendali, kemudian dilakukan perancangan dan pengujian pengendali PI dan PID.

Adapun kriteria perancangan sebagai berikut: 1. memiliki rise time yang cepat

2. overshoot sekecil mungkin

3. tidak memiliki steady state error.
Untuk memenuhi kriteria tersebut maka ditentukan spesifikasi sistem yang diinginkan sebagai beikut: Faktor redaman $\zeta=0.55$ Sehingga diperoleh Overshoot $\leq 12,6 \%$ dengan Fasa margin $\phi_{P M}=100 \varsigma=55^{\circ}$

Berdasarkan hasil pengujiaan sistem, dilakukan perbandingan unjuk kerja dari masing-masing pengendali PI dan PID dalam mengendalikan tegangan keluaran konverter buck. Parameter yang diamati dan dibandingkan adalah waktu naik (rise time), waktu mantap (setling time) dan simpang puncak (overshoot).

\section{HASIL DAN PEMBAHASAN}

\subsection{Pengujian Tanpa Pengendali}

Dalam artikel ini rangkaian konverter buck memiliki parameter sebagai berikut: $V_{\text {in }}=20 \mathrm{~V}$, $V_{0}=12 \mathrm{~V}, \mathrm{~L}=150 \mu \mathrm{H}, \mathrm{C}=1000 \mu \mathrm{F}$, dan $\mathrm{R}=$ $10 \Omega$. Tahanan dalam komponen $\mathrm{C}$ dan $\mathrm{L}$ berturut-turut sebesar $30 \mathrm{~m} \Omega$ dan $10 \mathrm{~m} \Omega$. Frekuensi penskalaran $20 \mathrm{kHz}$.

Dengan memasukan parameter-parameter konverter buck pada persamaan (9) diperoleh fungsi alih konverter buck sebagai berikut,

$$
\frac{\hat{v}_{o}(s)}{d(s)}=\frac{0,0006 s+20}{1,503 * 10^{-7} s^{2}+5,49810^{-5} s+1}
$$

Pengujian konverter buck tanpa pengendali dimaksudkan untuk memperoleh tanggapan sistem. Tanggapan tegangan keluaran dan tanggapan frekuensi konverter buck tanpa pengendali diperlihatkan berturut-turut pada Gambar 8 dan 9.

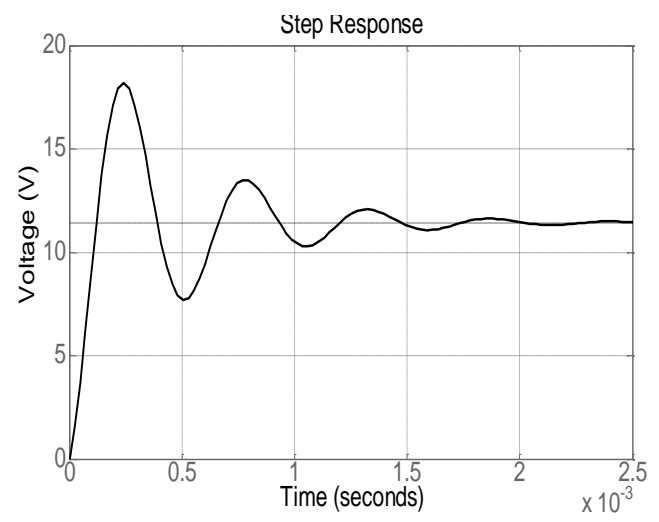

Gambar 8. Tanggapan lingkar tertutup (closed loop) tanpa pengendali 


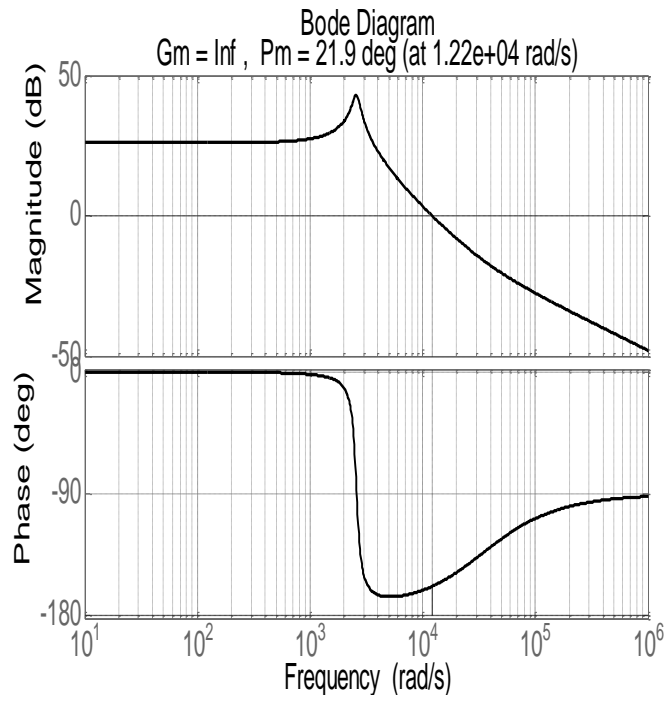

Gambar 9. Tanggapan frekuensi

Pada Gambar 8 diperlihatkan tanggapan tegangan keluaran konverter buck tanpa pengendali dengan overshoot sebesar 59,2\%, settling time sebesar 0,00167 detik, rise time sebesar 0.00009 detik dan tegangan keluaran buck konverter sebesar 11,4 Volt. Sedangkan margin fasa yang dihasilkan berdasarkan Gambar 9 adalah 21,9 ${ }^{0}$. Untuk memperbaiki tanggapan dinamik sistem dilakukan perancangan pengendali PI dan PID.

\subsection{Rancangan Pengendali PI}

Pengendali PI digunakan untuk menaikkan penguatan lingkar tertutup sistem dan menghilangkan atau memperkecil error keadaan steady state. Perancangan pengendali PI didasarkan pada tanggapan keluaran konverte rbuck tanpa pengendali menggunakan metoda tanggapan frekuensi. Sehingga diperoleh: $\angle \mathrm{G}\left(\mathrm{j} \omega_{w}\right)=\left(-180^{\circ} 55^{\circ}+5^{0}\right)=-120^{\circ}$. Berdasarkan tanggapan frekuensi lingkar terbuka sistem untuk $\angle-120^{\circ}$ diperoleh $\omega_{1}=2706,652 \mathrm{rad} / \mathrm{s}$ dengan $\left|G\left(j \omega_{1}\right) H\left(j \omega_{1}\right)\right|=11,545$. Parameter pengendali diperoleh dengan menggunakan persamaan (19) dan (21), masing-masing $K_{i}=$ 2.4265, $K_{p}=0.0089$. Sehingga diperoleh persamaan fungsi alih pengendali PI sesuai persamaan(18),

$G_{c}(s)=\frac{0,0089 s+2,4265}{s}$

Pada Gambar 10 terlihat, tegangan keluaran konverter buck menuju 12 Volt, tanpa mengalami overshoot. Osilasi hanya terjadi di titik awal. Setelah mencapai tegangan referensinya tidak ada lagi osilasi.

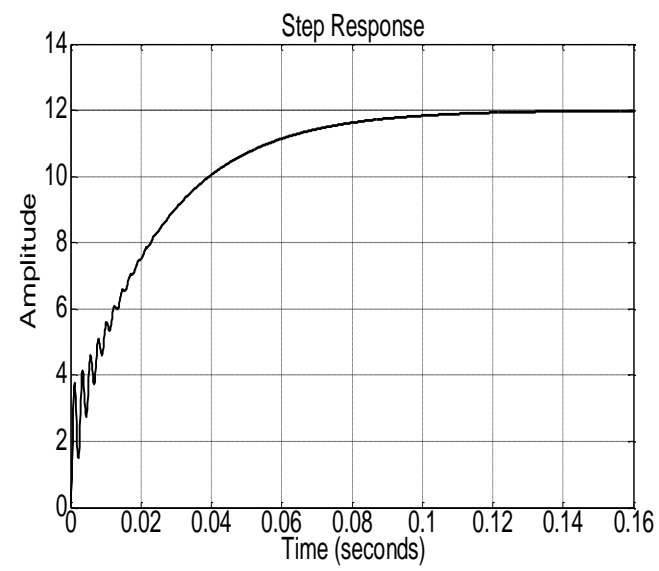

Gambar 10. Tanggapan pengendali PI

Tanggapan pengendali PI pada Gambar 10 ini memperlihatkan bahwa pengendali PI dapat menghilangkan overshoot dan error dalam keadaan steady state tetapi terjadi peningkatan pada settling time dan rise time. Besarnya settling time dan rise time berturut- turut adalah 0.091 detik dan 0,0515 detik.

Bode plot pengendali PI diperlihatkan pada Gambar 11. Berdasarkan bode plot dapat dilihat bahwa phasa margin yang diperoleh sebesar $54,4^{0}$ pada $2700 \mathrm{rad} / \mathrm{sec}$.

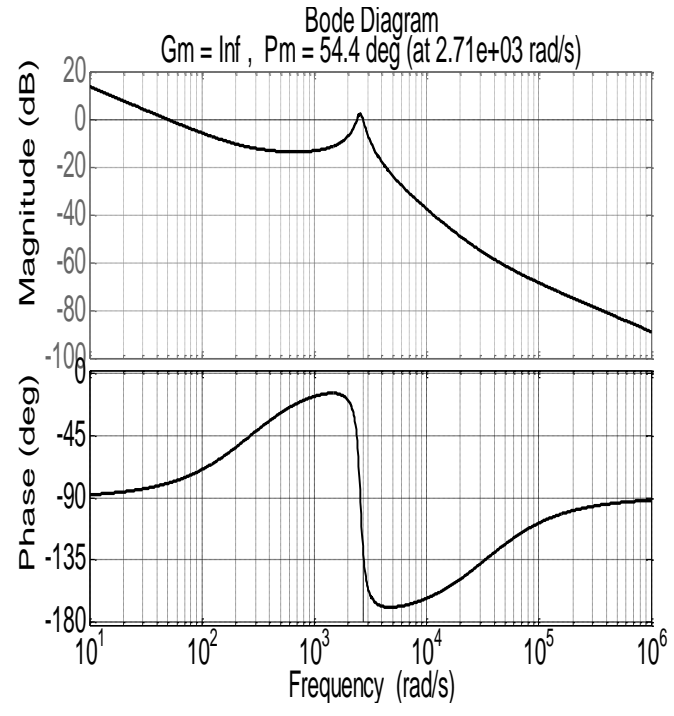

Gambar 11. Bode plot dengan pengendali PI

\subsection{Rancangan Pengendali PID}

Parameter pengendali PID yang diterapkan untuk memperbaiki unjuk kerja konverter buck 
diperoleh berdasarkan prosedur perancangan pengendali PID.

$\angle G\left(j \omega_{1}\right) H\left(j \omega_{1}\right)=\angle-180^{\circ}+55^{\circ}=-125^{\circ}$.

Berdasarkan respon frekuensi lingkar terbuka sistem untuk $\angle-125^{\circ}$ diperoleh $\omega=2738,02$ $\mathrm{rad} / \mathrm{s}$, sehingga $\omega_{1}$ harus dipilih besar dari $\omega$ dengan syarat $\left|G\left(j \omega_{1}\right) H\left(j \omega_{1}\right)\right| \angle 1$.

Berdasarkan ketentuan dan syarat perancangan pengendali PID, $\omega_{1}$ dipilih $12177,522 \mathrm{rad} / \mathrm{s}$. Untuk $\omega_{1}$ yang dipilih diperoleh $\left|G\left(j \omega_{1}\right) H\left(j \omega_{1}\right)\right|=0.9997$ dengan sudut fasa sebesar $-158,13^{0}$. Sehingga $\angle$ $\mathrm{G}\left(\mathrm{j} \omega_{w}\right)=\left(-180^{\circ}+55^{\circ}+158,13^{0}\right)=33,13^{0}$. Nilai $K_{p}, \quad K_{i}$ dan $K_{d}$ berturut-turut diperoleh berdasarkan persamaan (25),(21) dan (26) sebagai berikut: $K_{i}=1020,07, K_{p}=0,83766$ dan $K_{d}=5,177 \times 10^{-5}$. Persamaan pengendali PID ditulis,

$$
G_{c}(s)=0,83766+\frac{1020,07}{s}+5,177 \times 10^{-5} s
$$

Sedangkan tanggapan tegangan keluaran dan bode plot konverter buck menggunakan pengendali PID dapat dilihat pada Gambar 12 dan 13.

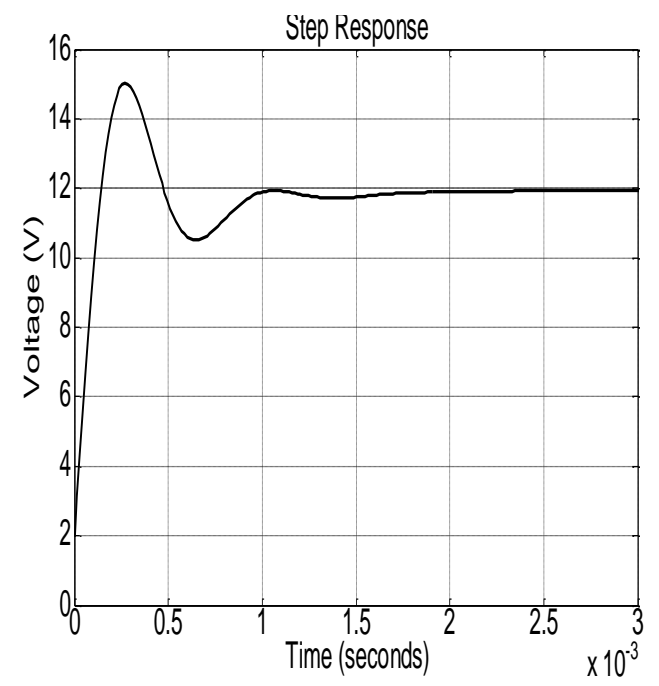

Gambar 12. Tanggapan lingkar tertutup dengan Pengendali PID

Berdasarkan Gambar 12 dan 13 dapat dilihat penerapan pengendali PID mampu memperbaiki tanggapan peralihan sistem. Rise time yang dihasilkan sebesar 0.000102 detik dan settling time sebesar 0,00143 detik.

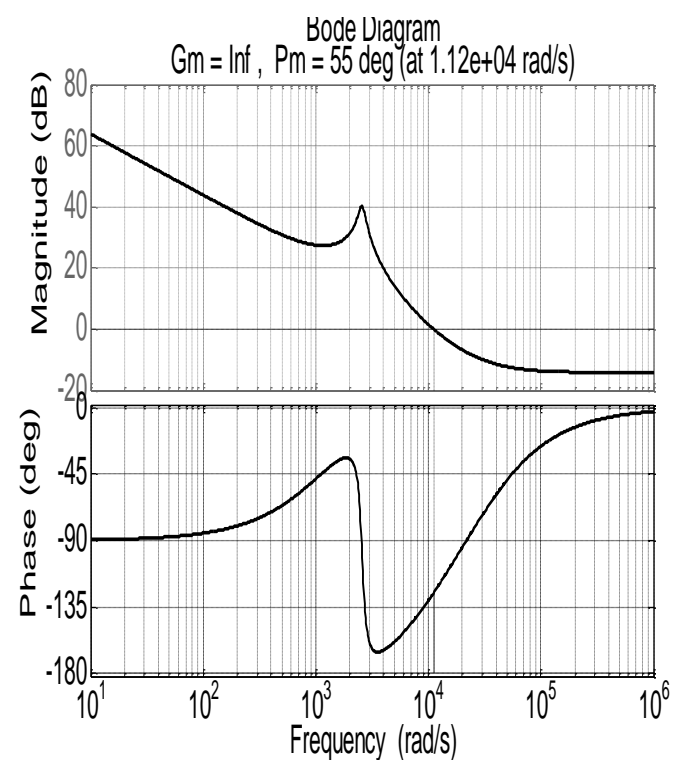

Gambar 13. Bode plot dengan pengendali PID

Pengendali mampu mengurangi overshoot dan menghilangkan error dalam keadaan steady state, overshoot yang dihasilkan sebesar $26 \%$ dengan fasa margin $55^{\circ}$ pada $12200 \mathrm{rad} / \mathrm{sec}$. Berarti penerapan pengendali PID mampu memenuhi kriteria yang diinginkan.

\section{KESIMPULAN}

Berdasarkan hasil pengujian yang dilakukan pada pengendalian tegangan keluaran konverter buck dengan penerapan pengendali PI dan PID dapat disimpulkan sebagai berikut:

1. Pengendali PI mampu meminimumkan overshoot, tetapi respon sistem menjadi lebih lambat dengan terjadi peningkatan pada rise time dan settling time serta timbulnya osilasi pada awal respon sistem.

2. Penerapan pengendali PID mampu meningkatkan kecepatan respon sistem yang berhubungan dengan rise time dan settling time, sedangkan dalam hal overshoot pengendali PID mampu mengurangi overshoot dengan nilai maksimum $26 \%$.

3. Pengendali PID mampu memperbaiki respon transien sistem dengan menghilangkan osilasi dan meningkatkan kecepatan respon sistem yang meliputi rise time dan settling time, sehingga dapat disimpulkan pengendali PID memiliki performansi lebih baik dibandingkan pengendali PI pada pengendalian tegangan keluaran konverter buck yang ditinjau. 


\section{DAFTAR PUSTAKA}

[1] D. M. M. S. Prabha, S. P. Kumar, and G. G. Devadhas, "Anoptimum setting of controller for a dc-dc converter using bacterial intelligence technique," in Proc. PES Innovative Smart Grid Technologies Conf., 2011, pp. 204-210.

[2] M. Namnabat, M. B. Poudeh, and S. Eshtehardiha, "Comparison the control methods in improvement the performance of the DC-DC converter," in Proc. Power Electronics Conf., 2007, pp. 246-251

[3] N. R Mude, and Ashish Sahu, "Adaptive Control Schemes For DC- DC Buck Converter" International Journal of Engineering Research and Applications, Vol. 2, Issue 3, May-Jun 2012, pp. 463-467

[4] M. Kheirmand, M. Mahdavian, M. B. Poudeh, and S.Eshtehardiha, "Intelligent modern controller on DC-DC converter," in Proc. IEEE Region 10 Conf., 2008, pp. 1-5.

[5] K. Wei, Q. Sun, B. Liang, and M. Du, "The research of adaptivefuzzy PID control algorithm based on LQR approach in DCDCconverter," in Proc. Computational Intelligence Conf., vol. 1,2008, pp. 139143.

[6] P. Gupta and A. Patra, "Hybrid sliding mode control of DC-DC power converter circuits," in Proc. Convergent Technologies forthe Acia-Pacific Region Conf., vol. 1, 2003, pp. 259-263.

[7] G. Keller, D. Lascu, and J. M. A. Myrzik, "State-space control structures for buck converters with/without input filter," in Proc. Power Electronics and Applications Conf., 2005, pp. 1-10.

[8] Eka Prasetyono, Wima Ashary, Anang Tjahjono, Novie Ayub Windarko, "Studi Komparasi Fungsi Keanggotaan Fuzzy sebagai Kontroler Bidirectional DC-DC Converter pada Sistem Penyimpan Energi" Jurnal Nasional Teknik Elektro Vol 4, No 2: September 2015, pp. 220 - 226

[9] İ. Atacak and Ö. F. Bay, "Tuning gain parameters of a PI controller using genetic algorithm for boost $\mathrm{dc}-\mathrm{dc}$ converter," in Proc. International Advanced Technologies Symp., 2009, pp. 221-225.

[10] H. N. Koivo, "Tuning of a multivariable PID-controller for unknown systems," in Proc. IEEE Decision and Control Including the Symposium on Adaptive Processes Conf., vol. 19,1980, pp. 1158-1159.

[11] D. M. Bain and G. D. Martin, "Simple PID tuning and PID closed loop simulation," in Proc. American Control Conference Conf., 1983, pp. 338-341.

[12] J. G. Ziegler, N. B. Nichols, and N. Y. Rochester, "Optimum settings for automatic controllers," Transactions of the ASME, vol.64, pp. 759-768, 1942.

[13] Phillips, L. Charles and Phillips, RoyceD. Harbor, Feedback Control Systems,. $4^{\text {th }}$ Edition, Prentice Hall International, 2000

[14] Ogata, K, Modern Control Engineering, Fifth Edition, Pearson Education, Inc., 2010.

\section{Biodata Penulis}

Irma Husnaini, menamatkan pendidikan S1 di Jurusan Teknik Elektro Universitas Bung Hatta (UBH) pada tahun 1998, dan jenjang pendidikan S2 diselesaikan di Departemen Teknik Elektro Institut Teknologi Bandung (ITB) dengan konsentrasi bidang teknik kendali pada tahun 2005. Saat ini Penulis terdaftar sebagai dosen di Jurusan Teknik Elektro Universitas Negeri Padang (UNP). Minat penelitian Penulis adalah pemprosesan sinyal dan kendali derau aktif.

Krismadinata, menamatkan pendidikan S1 di Jurusan Teknik Elektro Universitas Andalas (UNAND) tahun 2000, S2 di Departemen Teknik Elektro Institut Teknologi Bandung (ITB) tahun 2004 dan S3 di Department of Electrical Engineering University of Malaya, Kuala Lumpur Malaysia tahun 2012, serta Postdoctoral di UMPEDAC 2014. Penulis saat ini adalah Dosen Teknik Elektro Universitas Negeri Padang. Minat penelitian Penulis adalah elektronika daya dan sistem kendali dalam energi terbarukan. 